\title{
elsevier_POLY_12746
}

\section{Ruthenium(II) pincer complexes featuring an anionic CNC bis(1,2,3-triazol-5-ylidene)carbazolide ligand coordinated in a meridional fashion}

\section{George Kleinhans}

Gregorio Guisado-Barrios ${ }^{\mathrm{b},}$

guisado@uji.es

Eduardo Peris ${ }^{b}$

\section{Daniela I. Bezuidenhouta, $\mathrm{c}, *$}

daniela.bezuidenhout@wits.ac.za

${ }^{a}$ Chemistry Department, University of Pretoria, Private Bag X20, Hatfield 0028, Pretoria, South Africa

bInstitute of Advanced Materials (INAM), Universitat Jaume I, Avenida Vicente Sos Baynat s/n, 12071 Castellon, Spain

'Molecular Sciences Institute, School of Chemistry, University of the Witwatersrand, Johannesburg 2050, South Africa

${ }^{*}$ Corresponding authors at: Molecular Sciences Institute, School of Chemistry, University of the Witwatersrand, Johannesburg 2050, South Africa (D.I. Bezuidenhout).

Abstract

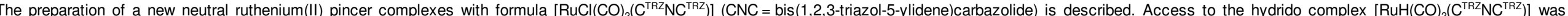

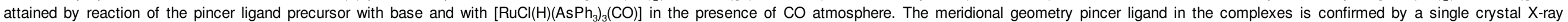
diffraction study of $\left[\mathrm{RuCl}(\mathrm{CO})_{2}\left(\mathrm{C}^{\mathrm{TRZ}} \mathrm{NC}{ }^{\mathrm{TRZ}}\right)\right]$. Preliminary results of the use of $\left[\mathrm{RuCl}(\mathrm{CO})_{2}\left(\mathrm{C}^{\mathrm{TRZ}} \mathrm{NC}{ }^{\mathrm{TRZ}}\right)\right]$ as catalyst in the transfer hydrogenation reaction of ketones, are reported.

Keywords: Ruthenium(II); Mesoionic carbene (MIC); Pincer ligands; 1,2,3-Triazol-5-ylidene (TRZ); Meridional coordination

\section{Introduction}

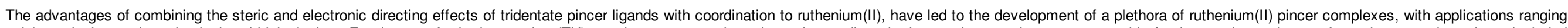

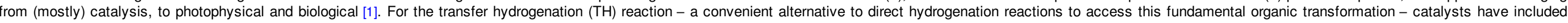

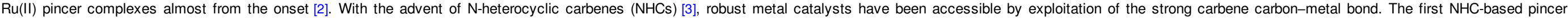
complexes of Ru(II) utilized in TH contained tridentate CNC-ligands with a central pyridine as N-donor group, and flanking NHCs as C-donors, see A [4] and B [5], Fig. 1. 
<smiles></smiles>

A $[R u]=\mathrm{RuCl}_{2} \mathrm{PPh}_{3}$ (Danopoulos, 2002)

B $[\mathrm{Ru}]=\mathrm{Ru}(\mathrm{CO}) \mathrm{Br}_{2}$ (Peris, 2003)

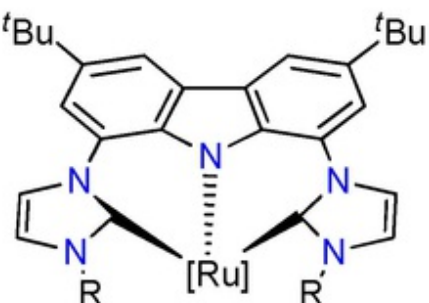

$E[R u]=R u C p *$

(Kunz, 2017)

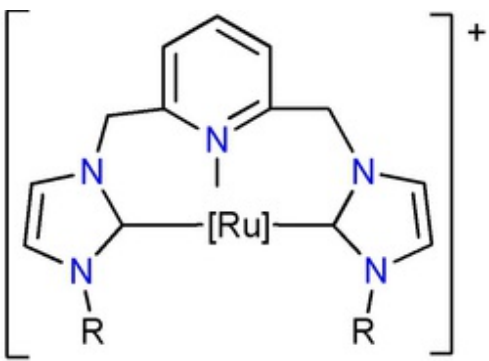

C $[\mathrm{Ru}]=\mathrm{Ru}(\mathrm{CO})_{2} \mathrm{H}$ (Hor, Luo 2016)

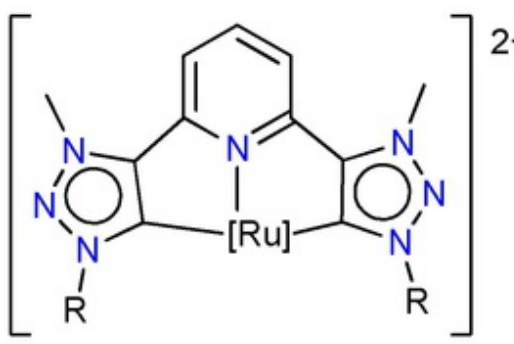

$F[R u]=R u(t e r p y)$

(Gonzalez, Schubert, 2011)<smiles>CCCCC1N(CC)CCN2CCN3C=CN(CC)C3C12C</smiles>

D $[\mathrm{Ru}]=\mathrm{Ru}(\mu-\mathrm{Cl})_{3}$ (Pidko, 2015)

Fig. 1 Examples of previously reported carbene-based CNC-Ru(II) complexes.

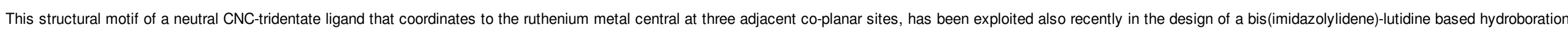

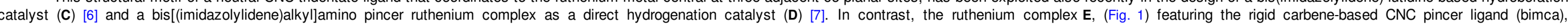

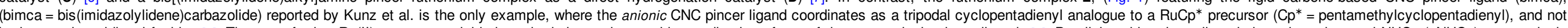

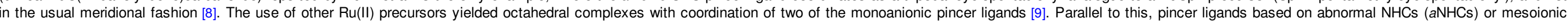

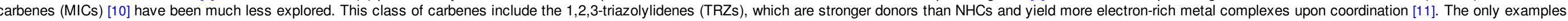

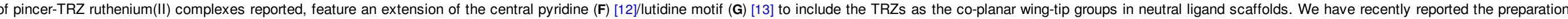

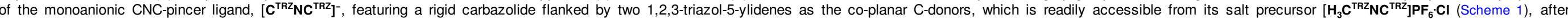

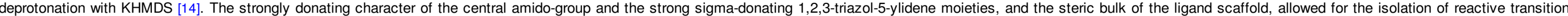

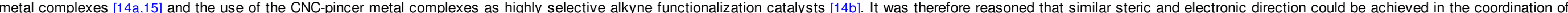
$\left[\mathrm{C}^{\mathrm{TRZ}} \mathrm{NC}^{\mathrm{TRZ}}\right]^{-}$to an appropriate ruthenium(II) precursor. 


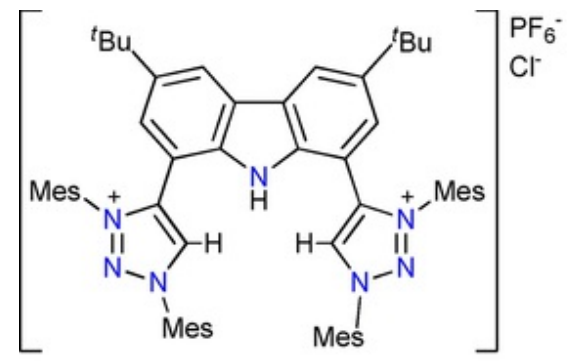

$\left[\mathrm{H}_{3} \mathrm{C}^{\mathrm{TRZ}} \mathrm{NC}^{\mathrm{TRZ}}\right] \mathrm{PF}_{6} . \mathrm{Cl}$

$$
\begin{gathered}
{\left[\mathrm{RuHCl}(\mathrm{CO})(\mathrm{L})_{3}\right]} \\
\mathrm{KN}\left[\mathrm{Si}\left(\mathrm{CH}_{3}\right)_{3}\right]_{2} \\
\mathrm{THF} \\
-78^{\circ} \mathrm{C}-\mathrm{RT}
\end{gathered}
$$

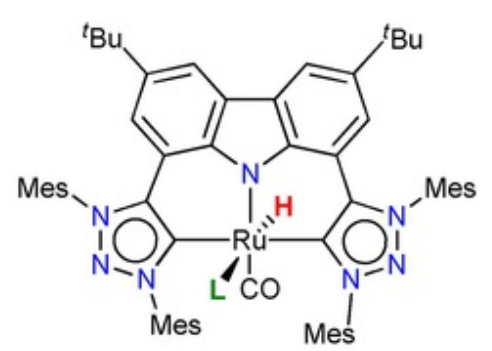

\section{$2\left[\mathrm{RuH}\left(\mathrm{AsPh}_{3}\right)(\mathrm{CO})\left(\mathrm{C}^{\mathrm{TRZ}} \mathrm{NC}^{\mathrm{TRZ}}\right)\right]$}

$\mathrm{NBD}=$ norbornadiene

Mes $=$ 2,4,6-trimethylphenyl

$$
\mathrm{L}=\mathrm{AsPh}_{3}
$$

Scheme 1 Synthesis of complexes 1-3.

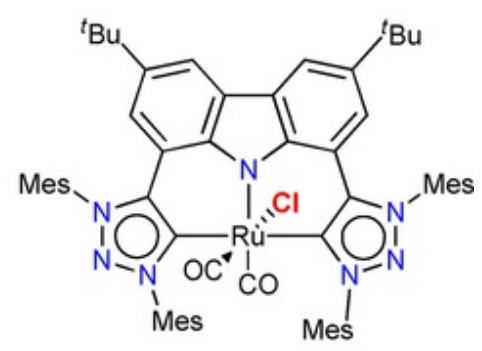

$1\left[\mathrm{RuCl}(\mathrm{CO})_{2}\left(\mathrm{C}^{\mathrm{TRZ}} \mathrm{NC}{ }^{\mathrm{TRZ}}\right)\right]$

$(14 \%)$

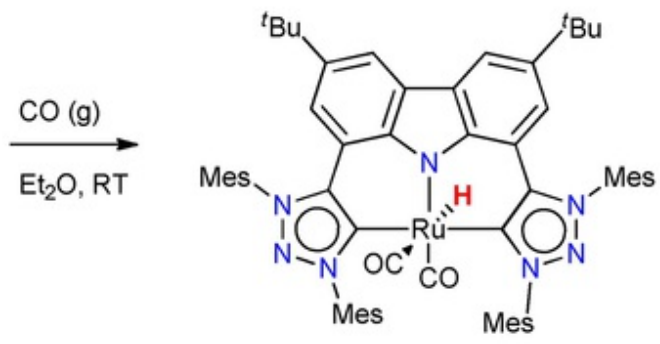

$3\left[\mathrm{RuH}(\mathrm{CO})_{2}\left(\mathrm{C}^{\mathrm{TRZ}} \mathrm{NC}^{\mathrm{TRZ}}\right)\right]$ (overall $17 \%$ )

\section{Experimental}

\subsection{Solvents and reagents}

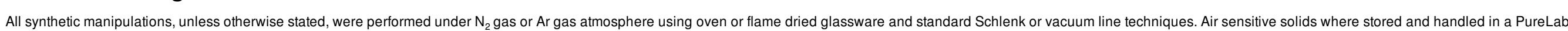

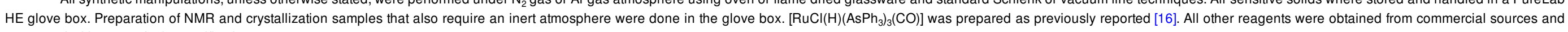
were used without any further purification.

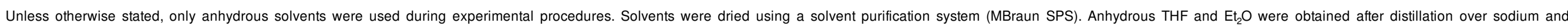

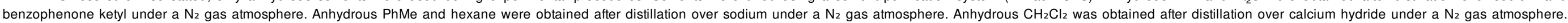
Deuterated benzene was dried over sodium and distilled under an Ar gas atmosphere.

\subsection{Characterization techniques}

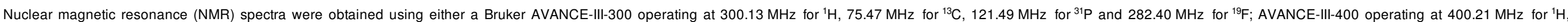

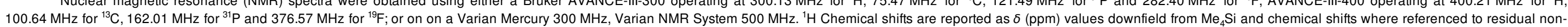




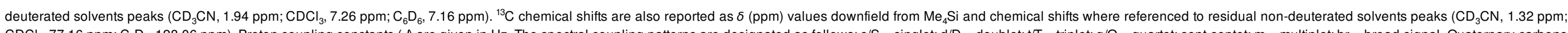

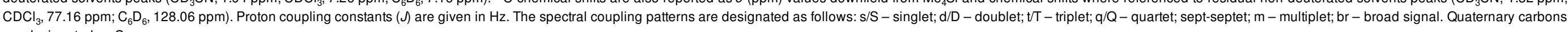
are designated as $\mathrm{C}_{\mathrm{q}}$.

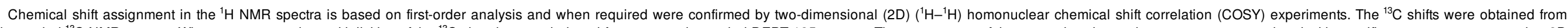

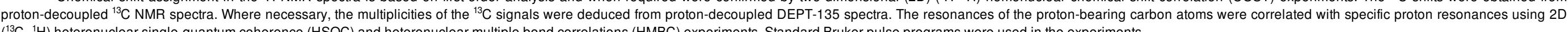
$\left({ }^{13} \mathrm{C}-{ }^{-1} \mathrm{H}\right)$ heteronuclear single-quantum coherence (HSQC) and heteronuclear multiple bond correlations (HMBC) experiments. Standard Bruker pulse programs were used in the experiments.

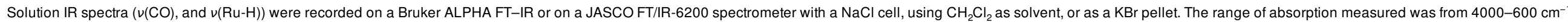

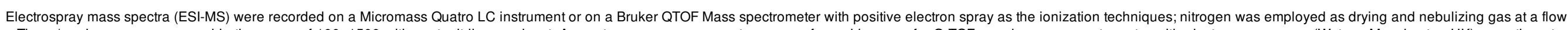

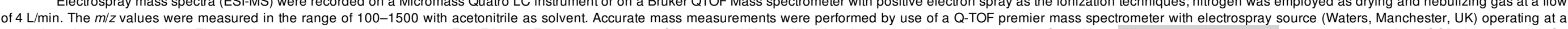

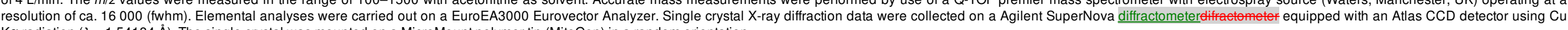
K $\alpha$ radiation $(\lambda=1.54184 \AA$ A). The single crystal was mounted on a MicroMount polymer tip (MiteGen) in a random orientation.

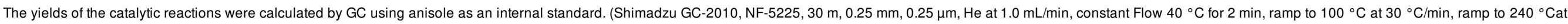
$45^{\circ} \mathrm{C} / \mathrm{min}$ (hold $0.5 \mathrm{~min}$ ).

\subsection{Crystal structure determination}

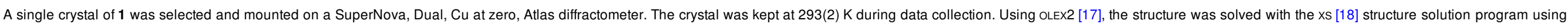
Direct Methods and refined with the SHELXL [18] refinement package using Least Squares minimization.

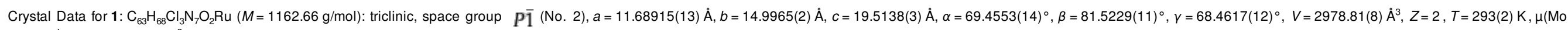

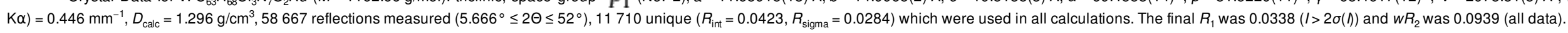

\subsection{Synthesis of complex 1 , $\left[\mathrm{RuCl}(\mathrm{CO})_{2}\left(\mathrm{C}^{\mathrm{TRz}} \mathrm{NC}^{\mathrm{TRz}}\right)\right]$}

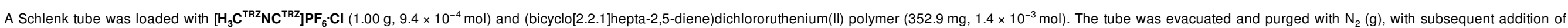

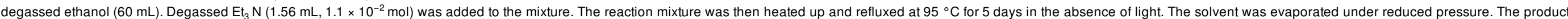

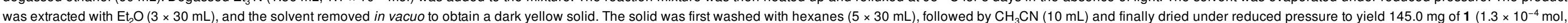

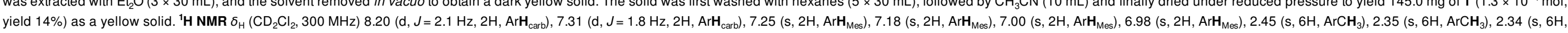

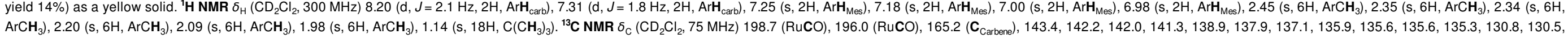

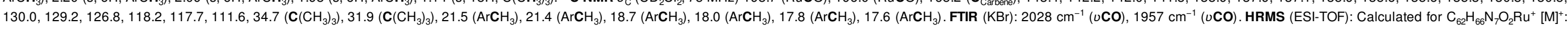
1042.4321, found: 1042.4343. Elemental analysis calc. (\%) for $\mathrm{C}_{62} \mathrm{H}_{66} \mathrm{~N}_{7} \mathrm{O}_{2} \mathrm{RuCl}$ : C 69.1, $\mathrm{H}$ 6.1, N 9.1; found 68.3, H 6.0, N 8.6.

\subsection{Synthesis of complex 2, $\left[\mathrm{RuH}\left(\mathrm{AsPh}_{3}\right)(\mathrm{CO})\left(\mathrm{C}^{\mathrm{rRz}} \mathrm{NC}^{\mathrm{Trz}}\right)\right]$}

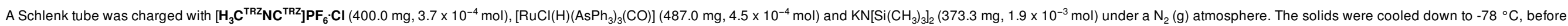

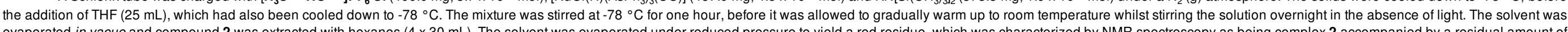

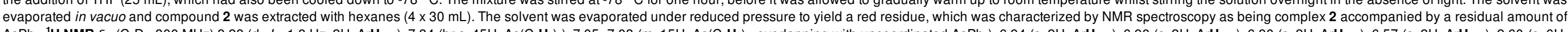

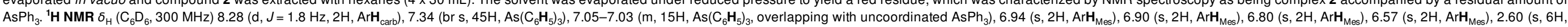

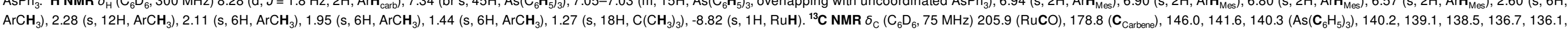

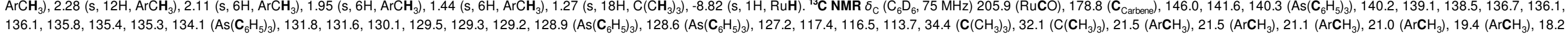
$\left(\mathrm{ArCH}_{3}\right), 18.1\left(\mathrm{ArCH}_{3}\right), 18.0\left(\mathrm{ArCH}_{3}\right), 18.0\left(\mathrm{ArCH}_{3}\right), 17.2\left(\mathrm{ArCH}_{3}\right)$.

\subsection{Synthesis of complex 3, $\left[\mathrm{RuH}(\mathrm{CO})_{2}\left(\mathrm{C}^{\mathrm{TRz}} \mathrm{NC}^{\mathrm{TRz}}\right)\right]$}

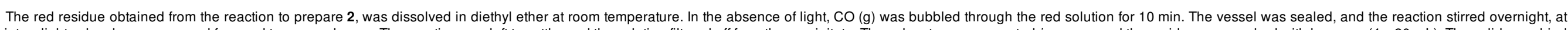

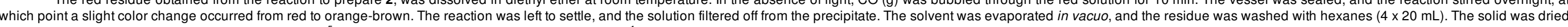

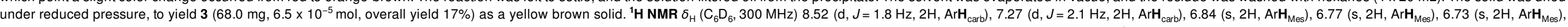

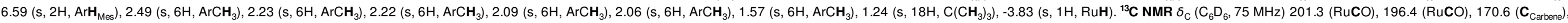

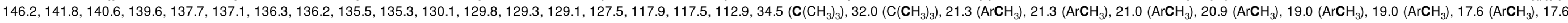

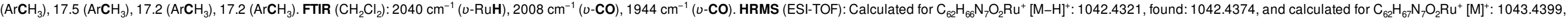
found: 1043.4391 .

\section{Results and discussion}

\subsection{Synthesis and characterization of dicarbonylchloridobis(1,2,3-triazol-5-ylidene)carbazolideruthenium(II) complex}

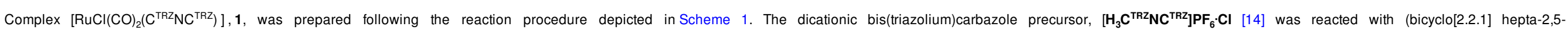




\section{elsevier_POLY_12746}

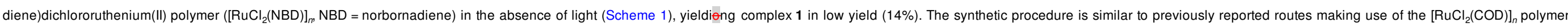
$(\mathrm{COD}=1,5$-cyclooctadiene) as precursor to yield dihalo monocarbonyl pincer complexes [5,19]. In our case the dicarbony/ monochloride CNC complex 1 was formed due to the anionic (and electron donating) nature of the CNC ligand.

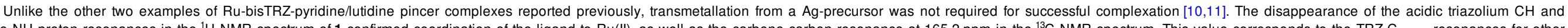

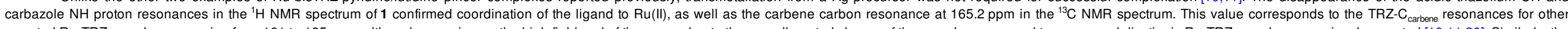

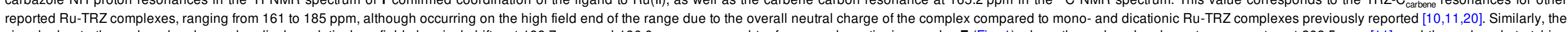

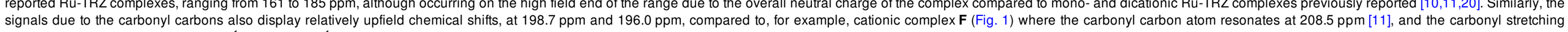
signals due to the carbonyl carbons also display relativencies are observed at $2028 \mathrm{~cm}^{-1}$ and $1957 \mathrm{~cm}^{-1}$.
frequen

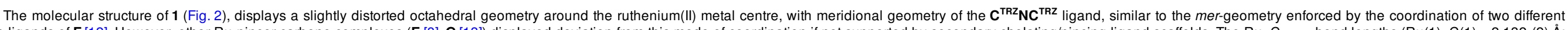

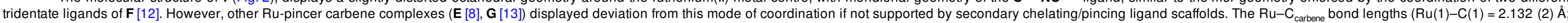

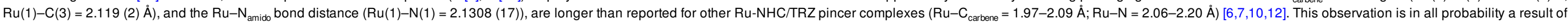

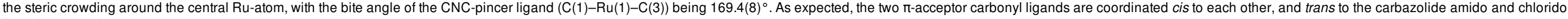
ligands, respectively.

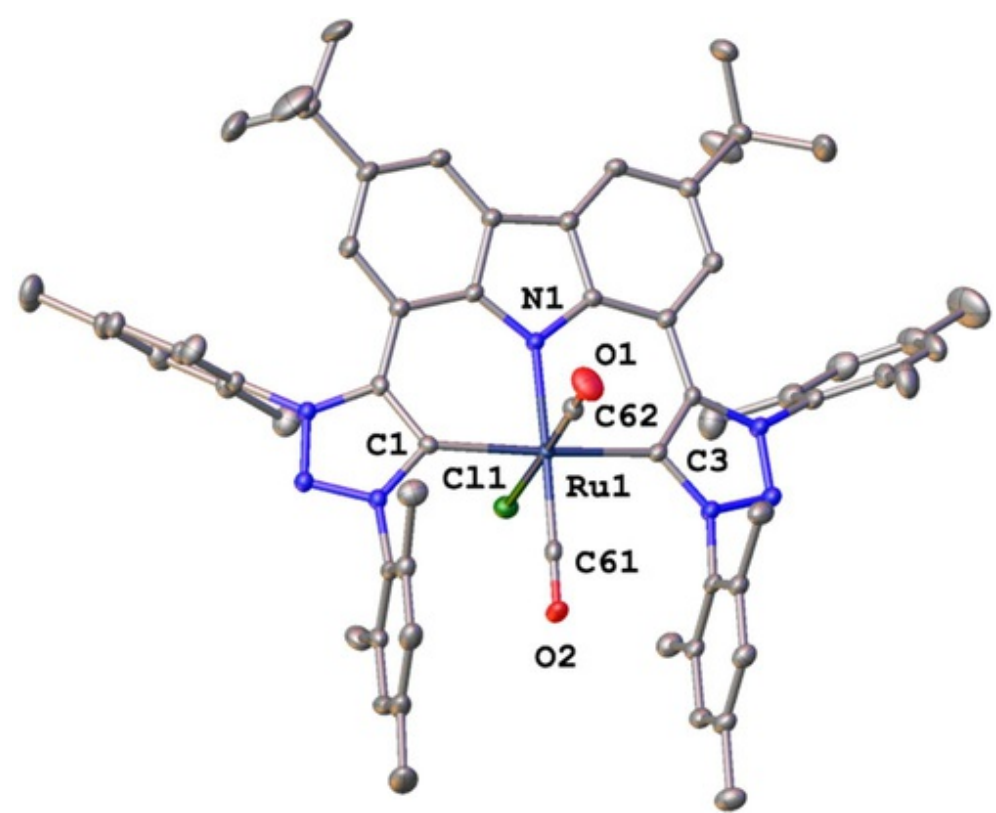

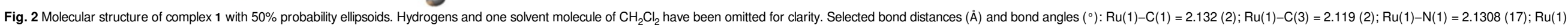
$-\mathrm{C}(61)=1.888(2) ; \mathrm{Ru}(1)-\mathrm{C}(62)=1.853(2) ; \mathrm{Ru}(1)-\mathrm{Cl}(1)=2.460(5) ; \mathrm{C}(1)-\mathrm{Ru}(1)-\mathrm{C}(3)=169.4(8) ; \mathrm{N}(1)-\mathrm{Ru}(1)-\mathrm{C}(61)=176.7(8) ; \mathrm{N}(1)-\mathrm{Ru}(1)-\mathrm{Cl}(1)=88.1(5)]$

\subsection{Synthesis and characterization of dicarbonylhydridoridebis(1,2,3-triazol-5-ylidene)carbazolide ruthenium(II) complex}

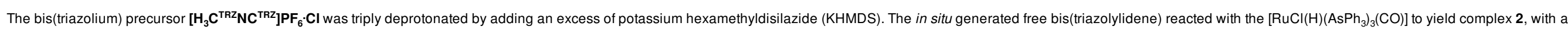

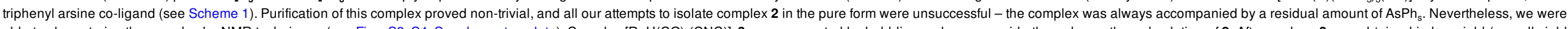

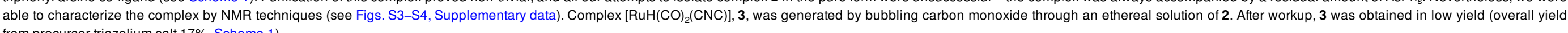
from precursor triazolium salt $17 \%$, Scheme 1).

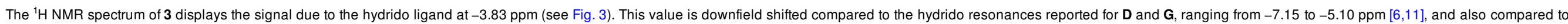

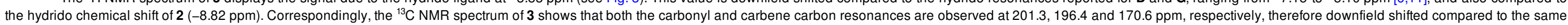

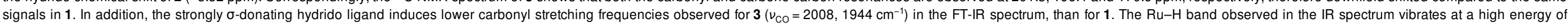
$2040 \mathrm{~cm}^{-1}$, although such a high wavenumber $\nu_{\mathrm{Ru}-\mathrm{H}}$ is not unprecedented in the literature [21]. In the case of complex 2 , carbene and carbonyl carbon resonances were observed at 205.9 and $178.8 \mathrm{ppm}$, respectively. 


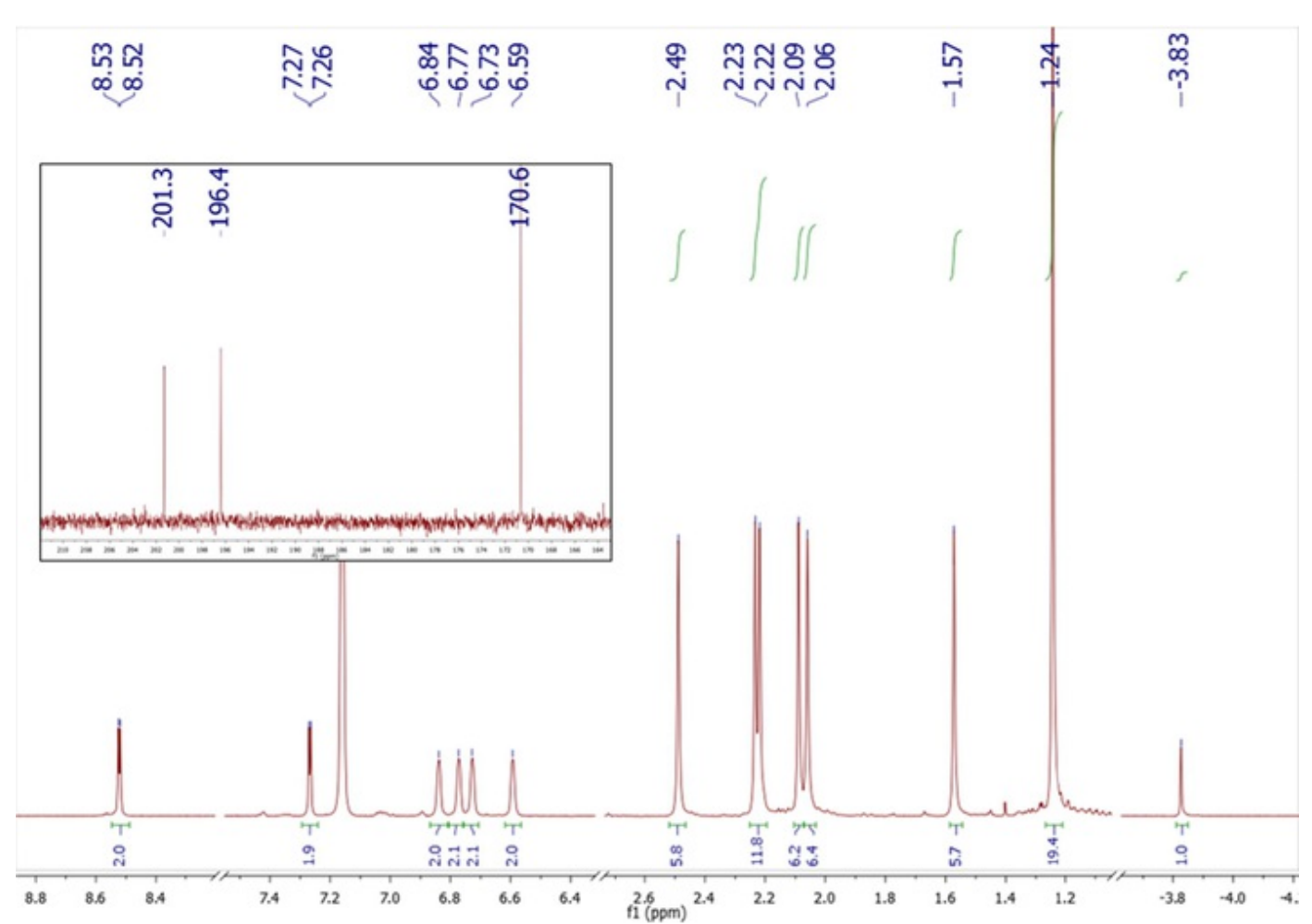

Fig. $3^{1} \mathrm{H}$ and ${ }^{13} \mathrm{C}$ (inset) NMR spectrum of 3

\subsection{Transfer hydrogenation of ketones}

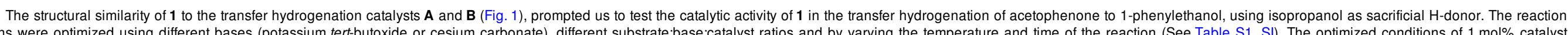

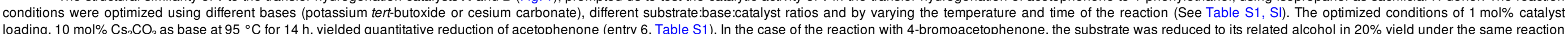

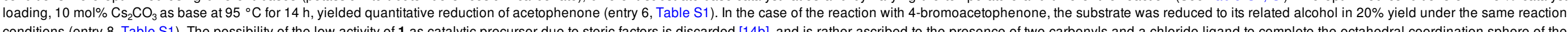

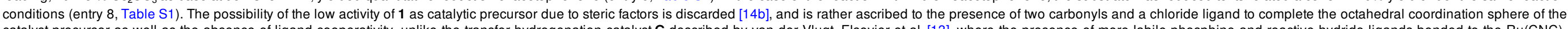

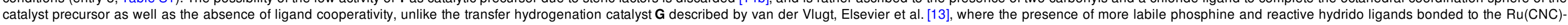
moiety combined with the pincer ligand cooperativity yield a more active catalyst.

\section{Conclusions}

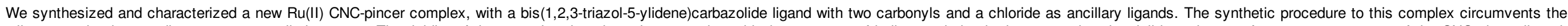

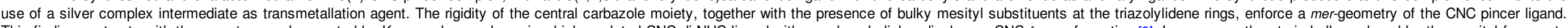

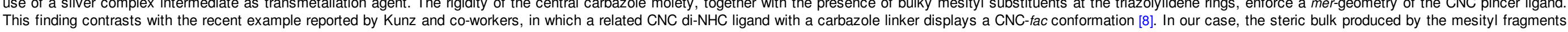

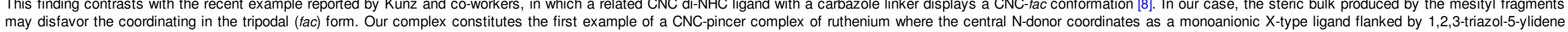

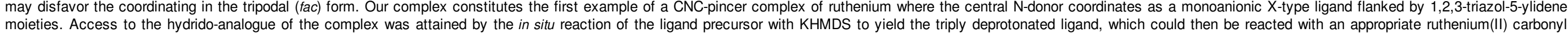

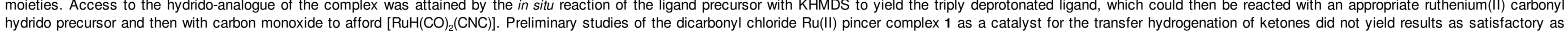
hydrido precursor and then with carbon monoxide to afford $\left[\mathrm{RuH}(\mathrm{CO})_{2}(\mathrm{CNC})\right]$. Preliminary studies of the dicarbonyl chloride $\mathrm{Ru}(\mathrm{II})$ pincer complex 1 as
expected. We are currently exploring the use of these complexes as catalysts in other model organic transformations, including amination reactions.

\section{Acknowledgements}

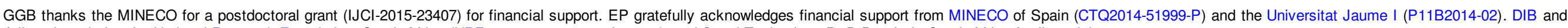
GK gratefully acknowledge the National Research Foundation, South Africa (NRF 10552, 105740 and 92521), and Sasol Technology R\&D Pty. Ltd., South Africa for financial support.

\section{Appendix A. Supplementary data}

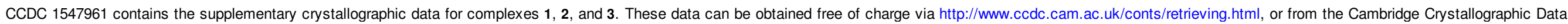




\section{elsevier_POLY_12746}

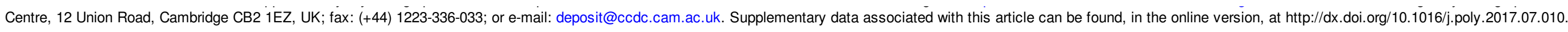

\section{References}

[1]

(a) For recent reviews, see:M. Asay and D. Morales-Morales, . Top. Organomet. Chem. 54, 2016, 239;

(b) H.A. Younus, W. Su, N. Ahmad, S. Chen and F. Verpoort, Adv. Synth. Catal. 357, 2015, 283;

(c) G. van Koten and R.A. Gossage, The Privileged Pincer-Metal Platform: Coordination Chemistry \& Applications, 2016, Springer International Publishing, Switzerland;

(d) M. Asay and D. Morales-Morales, Dalton Trans 44, 2015, 17432;

(e) C. Gunanathan and D. Milstein, Chem. Rev. 114, 2015, 12024;

(f) S. Werkmeister, K. Junge and M. Beller, Org. Process Res. Dev. 18, 2014, 289;

(g) K.J. Szabó and O.F. Wendt, Pincer and Pincer-Type Complexes: Applications in Organic Synthesis and Catalysis, 2014, Wiley Blackwell, Germany;

(h) H.A. Younus, N. Ahmad, W. Su and F. Verpoort, Coord. Chem. Rev. 276, 2014, 112;

(i) N. Cutillas, G.S. Yellol, C. de Haro, C. Vicente, V. Rodriguez and J. Ruiz, Coord. Chem. Rev. 257, 2013, 2784;

(j) G. van Koten and D. Milstein, Organometallic Pincer Chemistry, 2013, Springer International Publishing, Switzerland;

(k) S. Budagumpi, R.A. Hague and A.W. Salman, Coord. Chem. Rev. 256, 2012, 1787;

(l) M. Albrecht and M.M. Lindner, Dalton Trans. 40, 2011, 8733;

(m) D. Milstein, Top. Catal. 53, 2010, 915;

(n) M. Poyatos, J.A. Mata and E. Peris, Chem. Rev. 109, 2009, 3677;

(o) D. Pugh and A.A. Danopoulos, Coord. Chem. Rev. 251, 2007, 610;

(p) J.A. Mata, M. Poyatos and E. Peris, Coord. Chem. Rev. 251, 2007, 841;

(q) D. Morales-Morales and C.M. Jensen, The Chemistry of Pincer Compounds, 2007, Elsevier, Amsterdam;

(r) J.M. Serrano-Becerra and D. Morales-Morales, Curr. Org. Synth. 6 (6), 2009, 169;

(s) X. Hu and K. Meyer, J. Organomet. Chem. 690, 2005, 5474;

(t) E. Peris and R.H. Crabtree, Coord. Chem. Rev. 248, 2004, 2239;

(u) D. Morales-Morales, Rev. Soc. Quim. Mex. 48 (48), 2004, 338;

(v) M.E. van der Boom and D. Milstein, Chem. Rev. 103, 2003, 1759;

(w) M. Albrecht and G. van Koten, Angew. Chem. Int. Ed. 40, 2001, 3750.

[2]

D. Wang and D. Astruc, Chem. Rev. 115, 2015, 6621.

[3]

A.J. Arduengo, III, R.L. Harlow and M. Kline, J. Am. Chem. Soc. 113, 1991, 361.

[4]

A.A. Danopoulos, S. Winston and W.B. Motherwell, Chem. Commun. 2002, 1376.

[5]

M. Poyatos, J.A. Mata, E. Falomir, R.H. Crabtree and E. Peris, Organometallics 22, 2003, 1110.

[6]

C.K. Ng, J. Wu, T.S.A. Hor and H.-K. Luo, Chem. Commun. 52 (1845), 2016, 11842.

[7]

G.A. Filonenko, M.J.B. Aguila, E.N. Schulpen, R. van Putten, J. Wiecko, C. Müller, L. Lefort, E.J.M. Hensen and E.A. Pidko, J. Am. Chem. Soc. 137, $2015,7620$.

[8]

E. Jürgens and D. Kunz, Eur. J. Inorg. Chem. 2017, 233.

[9]

M. Moser, Dissertation, Heidelberg, 2007.

[10]

(a) For reviews on mesoionic carbenes, see:K.F. Donnelly, A. Petronilho and M. Albrecht, . Chem. Commun. 47, 2013, 1145;

(b) R.H. Crabtree, Coord. Chem. Rev. 257, 2013, 755;

(c) M. Melaimi, M. Soleilhavoup and G. Bertrand, Angew. Chem. Int. Ed. 49, 2010, 8810; 


\section{elsevier_POLY_12746}

(d) D. Martin, M. Melaimi, M. Soleilhavoup and G. Bertrand, Organometallics 30, 2011, 5304;

(e) A. Poulain, M. Iglesias and M. Albrecht, Curr. Org. Chem. 15, 2011, 3325;

(f) A. Kruger and M. Albrecht, Australian J. Chem. 64, 2011, 1113;

(g) M. Albrecht, Chimia 63, 2009, 105;

(h) O. Schuster, L. Yang, H.G. Raubenheimer and M. Albrecht, Chem. Rev. 109, 2009, 3445;

(i) M. Albrecht and K.J. Cavell, Organomet. Chem. 35, 2009, 47;

(j) M. Albrecht, Science 326, 2009, 532;

(k) P.L. Arnold and S. Pearson, Coord. Chem. Rev. 251, 2007, 596.

[11]

(a) P. Mathew, A. Neels and M. Albrecht, J. Am. Chem. Soc. 130, 2008, 13534;

(b) G. Guisado-Barrios, J. Bouffard, B. Donnadieu and G. Bertrand, Angew. Chem. Int. Ed. 49, 2010, 4759;

(c) J.D. Crowley, A.-L. Lee and K.J. Kilpin, Aust. J. Chem. 64, 2011, 1118;

(d) B. Schulze and U.S. Schubert, Chem. Soc. Rev. 43, 2014, 2522

[12]

(a) B. Schulze, D. Escudero, C. Friebe, R. Siebert, H. Görls, U. Köhn, E. Altuntas, A. Baumgartel, M.D. Hager, A. Winter, B. Dietzek, J. Popp, L. González and U.S. Schubert, Chem. Eur. J. 17, 2011, 5494;

(b) S. Sinn, B. Schulze, C. Friebe, D.G. Brown, M. Jäger, E. Altuntas, J. Kübel, O. Guntner, C.P. Berlinguette, B. Dietzek and U.S. Schubert, Inorg. Chem. 53, $2014,2083$.

[13]

S.N. Sluijter, T.J. Korstanje, J.I. van der Vlugt and C.J. Elsevier, J. Organomet. Chem. 2017, http://dx.doi.org/10.1016/j.jorganchem.2017.01.003.

[14]

(a) D.I. Bezuidenhout, G. Kleinhans, G. Guisado-Barrios, D.C. Liles, G. Ung and G. Bertrand, Chem. Commun. 50, 2014, 2431;

(b) G. Kleinhans, G. Guisado-Barrios, D.C. Liles, G. Bertrand and D.I. Bezuidenhout, Chem. Commun. 52, 2016, 3504.

[15]

G. Kleinhans, M.M. Hansmann, G. Guisado-Barrios, D.C. Liles, G. Bertrand and D.I. Bezuidenhout, J. Am. Chem. Soc. 138, 2016, 15873.

[16]

D. Spasyuk, S. Smith and D.G. Gusev, Angew. Chem. Int. Ed. 51, 2012, 2772.

[17]

O.V. Dolomanov, L.J. Bourhis, R.J. Gildea, J.A.K. Howard and H. Puschmann, J. Appl. Cryst. 42, 2009, 339

[18]

G.M. Sheldrick, Acta Cryst. A64, 2008, 112.

[19]

D.G. Gusev, M. Madott, F.M. Dolgushin, K.A. Lyssenko and M.Y. Antipin, Organometallics 19, 2000, 1734.

[20]

(a) S. Sabater, H. Müller-Bunz and M. Albrecht, Organometallics 35, 2016, 2256;

(b) J. Cai, X. Yang, K. Arumugam, C.W. Bielawski and J.L. Sessler, Organometallics 30, 2011, 5033.

[21]

(a) J.G. Malecki and A. Maron, Trans. Met. Chem. 37, 2012, 727;

(b) J. Zhang, G. Leitus, Y. Ben-David and D. Milstein, Angew. Chem. Int. Ed. 45, 2006, 1113.

\section{Appendix A. Supplementary data}

Multimedia Component 1

Supplementary data

\section{Graphical abstract}

Synthesis and structure of CNC-pincer complexes of Ru(II) based on a bis(triazolylidene)carbazolide scaffold to enforce meridional geometry. 


\section{elsevier_POLY_12746}
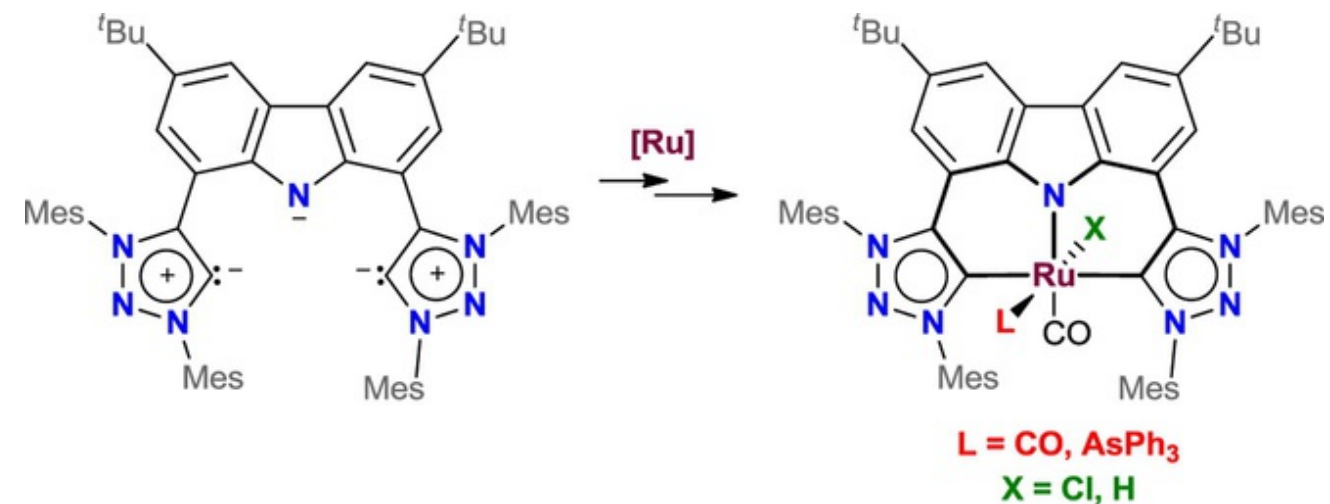

\section{Queries and Answers}

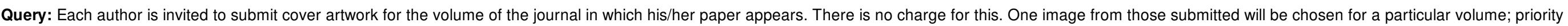

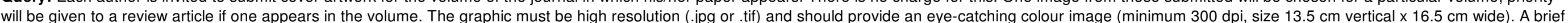

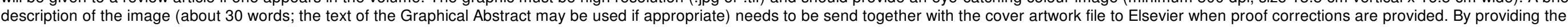

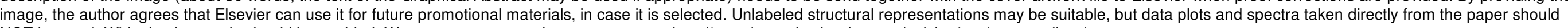
NOT be used. White backgrounds should be avoided. We suggest you examine past covers at http://www.journals.elsevier.com/polyhedron/cover-gallery/.

Answer: Correct

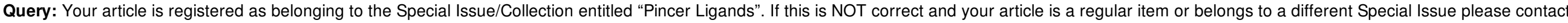
s.sravanthi@elsevier.com immediately prior to returning your corrections.

Answer: correct

Query: The author names have been tagged as given names and surnames (surnames are highlighted in teal color). Please confirm if they have been identified correctly.

Answer: correct

Query: Please check the address for the corresponding author "D.I. Bezuidenhout" that has been added here, and correct if necessary

Answer: correct

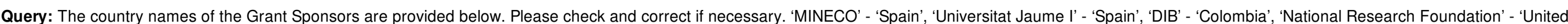
Arab Emirates', 'Sasol' - 'South Africa'.

Answer: For sponsor NRF, the country association for 'National Research Foundation' should be South Africa, NOT Colombia, United Arab Emirates

Query: One or more sponsor names may have been edited to a standard format that enables better searching and identification of your article. Please check and correct if necessary.

Answer: correct 